\title{
SERGEI MARTYNOVICH TROITSKII, 1930-1976
}

Sergei Martynovich Troitskii, who died suddenly in February of this year at the age of 45, was one of the most prominent younger Soviet historians and his death is a loss sorely felt both in the Soviet Union and in the West.

Born in 1930 in the Urals (in Cheliabinsk), the son of a teacher, he received his excellent and thorough professional training at the Historico-Archival Institute in Moscow. There he acquired his mastery of the archeographic craft and developed a passion for archival work. In 1962, after a stint as scholarly editor for "Sovetskaia Entsiklopediia" Publishing House, he joined the staff of the Institute of History of the Academy of Sciences in the USSR, rising to senior scientific worker (starshii nauchnyi sotrudnik) at the time of his death. Membership in the Institute enabled him to devote all of his time and boundless energy to research and writing: over a span of fifteen years he authored about a hundred articles and reviews, took active part as contributor and editor in numerous collective enterprises (symposia, sborniki, popularizations, and so forth), and wrote his two major contributions to eighteenth-century Russian history.

His first monograph, Finansovaia politika russkogo absolintizma $v$ XVII veke, published in 1966 (based on his kandidatskaia dissertatsiia of 1958), was a landmark in Soviet historiography. Bringing together and presenting a vast amount of archival and numerical data, Troitskii showed the basic character and development of the Russian state budget in the eighteenth century. Even more important than its specific contributions to the history of Russian fiscal policies, the monograph showed the "autonomy" and inner dynamics of imperial administrative history. In so doing, Troitskii's book restored the study of administrative institutions and policies of the Russian Empire to its rightful status and opened the way to welcome innovations in Soviet historiography.

In 1974 there appeared Russkii absoliutizm $i$ dvorianstr'o $v$ XVIII veke (Formirovanie biurokratii), which earned for Troitskii the coveted title of doctor of historical sciences at an unusually young age. Rarely was the reward better cleserved, for whatever criticisms one may level at it (and what truly significant work does not invite criticism?) it is a significant event in Russian historiography. In the first place, it brings to light a wealth of completely new (though some of it appeared earlier in articles) quantitative and qualitative data on the membership (numbers, social origins, family connections, education, wealth) and careers of the imperial bureaucracy in the first half of the eighteenth century. Second, it provides an account of the sources and legislative history of the Table of Ranks. Last, but not least, it illuminates the multifaceted character and complex development of the empire's ruling elite.

S. M. Troitskii displayed unusual enterprise and talent in ferreting out new sources in archives, a gift, alas, all too rarely found among his colleagues. $\mathrm{He}$ was also endowed with genuine historical sense, that is, a sense for what may be significant and interesting in illuminating the past-bringing together and correlating those several aspects of historical reality (for example, demography, agriculture, trade, economic ideas) which too often are treated in Soviet historiography as inert assemblages of disparate facts. Of course, Troitskii's work suffers from limitations as well-it would be doing his memory an injustice to ignore them. The most important one, it seems to me, is, of necessity, the use of a language (dia- 
lectical and hortatory) that, by its very nature, cannot adequately encompass the vivid empirical experience of the past.

Sergei Martynovich was a generous friend and colleague, always willing to share his knowledge and to help others in their archival search. Many an American exchange student and scholar will gratefully remember his help and advice.

Wer für seine eigene Zeit gelebt, der hat gelebt für alle

Zeiten

MARC RAEFF

Columbia University 